\title{
PENDAPATAN PETANI PADI SAWAH PENGGUNA PUPUK ORGANIK DAN ANORGANIK DI KABUPATEN OGAN KOMERING ULU (OKU) TIMUR
}

\author{
(RICE FARMER INCOME USING ORGANIC AND INORGANIC \\ FERTILIZERS IN EAST OGAN KOMERING ULU (OKU))
}

\author{
Siti Komariah Hildayanti 1, Andy Mulyana'2, Sriati², Nuni Gofar ${ }^{2}$ \\ ${ }^{1}$ Mahasiswa Program Doktor Ilmu Pertanian, Universitas Sriwijaya \\ ${ }^{2}$ Dosen Pengajar pada Jurusan Agribisnis, Universitas Sriwijaya \\ email: s.k.hildayanti@gmail.com
}

\begin{abstract}
Today eco-friendly rice farming system becomes interesting agribusiness among farmers, traders and regulators. The use of organic fertilizers as one of eco-friendly components in rice farming system is still low. In some rice production center the farmers of organic rice farming system looks higher than non-organic farmers. The question is: is there any difference among farmers whom use organic, semi-organic and inorganic fertilizers statistically? This research aims to know the difference of rice farmer income (organic and inorganic fertilizer) in East Ogan Komering Ulu (East$\mathrm{OKU})$, South Sumatra. The method used in this research is comparative analysis (independent t-test). The sample farmers are classified into the three clusters. The research shows that the contribution fertilizer cost from semi-organic farming is higher than full organic and inorganic farming. On the other side, $t$-test result shows that there is no different income among three kinds of using fertilizer.
\end{abstract}

Key words: income, farming, full organic, semi organic, inorganic fertilizer.

\section{PENDAHULUAN}

Potensi tanah yang subur menjadikan pertanian merupakan bagian budaya dan urat nadi kehidupan masyarakat Indonesia. Namun penggunaan pupuk anorganik dengan dosis tinggi hanya mampu meningkatkan produktivitas lahan pertanian dalam jangka pendek, sedangkan dalam jangka panjang terjadi stagnasi. Kondisi ini mengkhawatirkan kecukupan dan 
ketahanan bahan pangan nasional karena populasi penduduk Indonesia senantiasa meningkat dan masih mengandalkan beras sebagai sumber makanan pokok. Permintaan beras sebagai makanan utama sebagian besar penduduk Indonesia mengalami peningkatan dari tahun ke tahun. Peningkatan jumlah penduduk mendorong permintaan beras meningkat. Apabila tidak dilakukan peningkatan produktivitas dan perluasan areal panen, defisit beras di Indonesia akan meningkat sekitar 13,50 persen per tahun (Swastika dkk, 2000).

Berbagai upaya Revolusi Hijau saat ini tidak lagi memberikan kontribusi positif terhadap peningkatan produktivitas lahan sawah irigasi. Revolusi Hijau yang mengandalkan pupuk anorganik dan pestisida memiliki dampak negatif pada kesuburan tanah secara berkelanjutan serta mengakibatkan mutasi hama dan patogen yang tidak diinginkan. Lahan pertanian yang terus dipupuk dengan Urea $(\mathrm{N})$ ternyata hanya menunjukkan respon kesuburan tanaman seketika tetapi berdampak pada cepat habisnya bahan organik tanah hingga mencapai kurang dari satu persen. Penggunaan pupuk kimia, alkali, dan pestisida secara terus menerus akan menyebabkan terjadinya penumpukan residu melebihi daya dukung lingkungan dan meracuni tanah. Sebagai akibatnya, mikroba pengendali keseimbangan daya dukung kesuburan tanah akan hilang, terjadi ketidakseimbangan mineral, dan muncul organisme pengganggu tanaman yang kontra produktif.

Pemakaian pupuk anorganik secara intensif serta penggunaan bahan organik yang terabaikan untuk mengejar hasil yang tinggi, menjadi salah satu penyebab menurunnya unsur organik tanah. Akhir-akhir ini penggunaan bahan-bahan kimia berupa pupuk anorganik yang melebihi dosis telah menimbulkan masalah cukup serius. Ekosistem lahan pertanian menjadi rusak, predator alami hilang, dan keseimbangan unsur hara dalam tanah terganggu. Seranganhama dan penyakit pada tanaman makin meluas dan kegagalan panen pun makin sering dialami. Peningkatan produksi juga tidak berhasil diwujudkan meskipun jumlah penggunaan pupuk kimia telah ditingkatkan dua sampai tiga kali lipat dari sebelumnya. Namun upaya mengubah kebiasaan petani dari penggunaan pupuk anorganik ke organik membutuhkan waktu dan usaha ekstra keras terutama dari pemerintah dan pihak-pihak yang terkait di dunia pertanian.

Sumatera Selatan sebagai salah satu dari 34 provinsi di Indonesia memiliki lahan pertanian seluas 5.524 .725 hektar atau sekitar 70 persen dari seluruh wilayah daratannya, mencakup lahan persawahan dan ladang. Meski dampak positif penggunaan pupuk organik sudah jelas, penggunaan pupuk organik di Sumatera Selatan sampai saat ini masih rendah hanya kurang 10 persen dari seluruh total penggunaan pupuk urea dan jenis pupuk anorganik lainnya (Anonimous, 2012). Kabupaten Ogan Komering Ulu Timur merupakan salah satu kabupaten sentra penghasil beras di Provinsi Sumatera Selatan. 
Sebagian besar wilayah OKU Timur yaitu seluas 105.407 hektar atau 31,28 persen dimanfaatkan untuk sawah, dimana 23,16 persennya digunakan untuk sawah non irigasi, 7,71 persen sawah irigasi teknis dan sisanya berupa sawah irigasi setengah teknis. Sebagai sentra produksi beras petani di daerah mulai menggunakan pupuk organik sebagai pupuk utama diharapkan dapat memperbaiki lahan sawah sub optimal, meningkatkan produktifitas yang ada di wilayah tersebut, serta meningkatkan pendapatan. Sejauh mana penggunaan pupuk organik mampu meningkatkan produksi dan pendapatan petani dibandingkan terhadap penggunaan pupuk anorganik. Oleh karena itu tulisan ini mengulas mendalam tentang signifikansi pendapatan usahatani padi sawah pada petani pengguna pupuk organik dan pupuk anorganik di OKU Timur.

\section{METODE PENELITIAN}

Penelitian dilaksanakan di Kabupaten OKU Timur. Penentuan daerah dilakukan secara sengaja dengan pertimbangan sebagai sentra produksi beras terbesar di Sumatera Selatan serta mewakili jenis lahan irigasi. Metode yang digunakan adalah metode survei untuk menjangkau fakta yang terjadi di lapangan melalui kunjungan dan wawancara langsung. Teknik pengambilan sampel yaitu secara acak berlapis tidak berimbang, dimana populasi petani dikelompokkan atas petani padi sawah menggunakan pupuk organik, semi organik, dan pupuk anorganik. Jumlah sampel petani menggunakan pupuk organik sebanyak 81 , semi organik sebanyak 122 , sedangkan petani pengguna pupuk anorganik sebanyak 101 petani. Total sampel petani yaitu 304 orang.

Analisis yang dilakukan yaitu analisis komparatif dengan membandingkan pendapatan usahatani padi sawah yang sudah menggunakan pupuk organik (organik penuh dan semi organik) dengan yang tidak menggunakan pupuk organik sama sekali (anorganik). Untuk mengetahui perbedaan pendapatan antara usahatani padi sawah yang menggunakan pupuk organik dan yang tidak menggunakan pupuk organik, dilakukan uji beda dua sampel bebas (Independent Sample T Test).

\section{HASIL DAN PEMBAHASAN}

\section{Karakteristik Usahatani Petani}

Karakteristik berhubungan dengan usahatani padi sawah mencakup dua aspek utama yaitu struktur penggunaan input produksi serta struktur rata-rata biaya produksi, harga input, harga jual output dan pendapatan. Karakteristik ini berperan penting menggambarkan kinerja usahatani padi sawah. Secara rinci kedua aspek karakteristik usahatani ini dijelaskan berikut. 


\section{Struktur Penggunaan Input Produksi}

Tabel 1 menunjukkan jenis input produksi digunakan petani padi sawah secara umum relatif sama terdiri dari benih, pestisida, dan tenaga kerja. Perbedaan nyata terlihat dari jenis penggunaan pupuk yaitu pupuk organik dan anorganik. Uraian berikut menjelaskan tingkat pemakaian input produksi.

\section{Benih}

Tingkat penggunaan benih padi petani pengguna pupuk organik lebih tinggi dari kuantitas dianjurkan. Artinya kuantitas benih digunakan saat ini 1,16 lebih tinggi per hektar luas lahan digarap. Sementara penggunaan benih padi oleh petani pengguna pupuk semiorganik dan pengguna pupuk anorganik lebih rendah dari kuantitas benih yang dianjurkan. Tingkat penggunaan benih petani pengguna pupuk organik lebih tinggi dibandingkan tingkat penggunaan benih padi sawah oleh petani pengguna pupuk semiorganik dan pupuk anorganik. Perbedaan pupuk organik 1,7 kali lebih tinggi dibandingkan pupuk semi-organik atau 1,55 kali lebih tinggi dibandingkan pupuk anorganik. Sementara itu tingkat penggunaan benih padi petani pengguna pupuk semi-organik lebih rendah yaitu hanya 50 persen saja dari kuantitas dianjurkan sebesar $20 \mathrm{~kg}$ per hektar. Tingkat penggunaan benih pada petani pengguna pupuk anorganik lebih rendah yaitu 44,8 persen dari dosis anjuran ( $25 \mathrm{~kg}$ per hektar).

\section{Pupuk}

Jenis pupuk digunakan petani padi sawah berbeda-beda. Petani pengguna pupuk organik menggunakan pupuk oranik padat (POP), organik cair (POC) dan pelengkap cair (PPC). Penggunaan POP lebih besar dibandingkan penggunaan POC. Penggunaan POP mencapai 97,45 persen dibandingkan POC 0,97 persen. Penggunaan pupuk petani semi-organik didominasi pupuk kandang/petro, urea, SP-36 dan PPC. Penggunaan pupuk petro sebesar 65,84 persen, pupuk urea sebesar 19,74 persen, pupuk SP-36 sebesar 13,77 persen dan PPC sebesar 0,65 persen. Petani pengguna pupuk anorganik didominasi oleh pupuk urea mencapai 62,13 persen, pupuk SP-36 mencapai 36,50 persen dan PPC mencapai 1,37 persen. Penggunaan pupuk urea melebihi dosis anjuran, sehingga penggunaan input produksi seperti pupuk belum efisien (Sahara dan Idris, 2005) seperti terjadi di sentra produksi beras Konawe. 
Tabel 1. Penggunaan Input Produksi pada Usahatani Padi Sawah Organik, Semi-Organik dan Anorganik Kabupaten Ogan Komering Ulu Timur (OKUT)

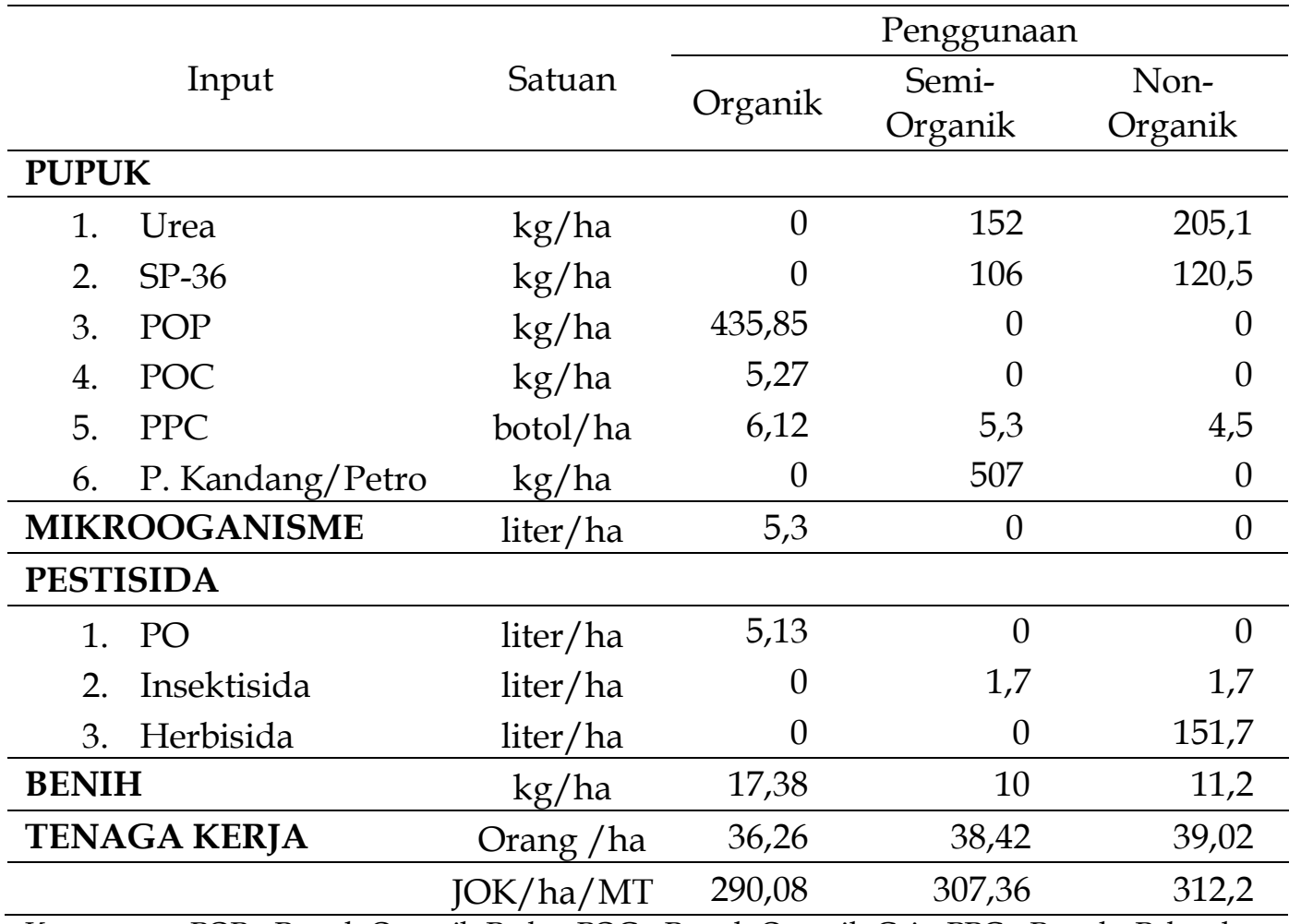

Keterangan: POP : Pupuk Organik Padat, POC : Pupuk Organik Cair, PPC : Pupuk Pelengkap Cair, MOL : Mikroorganisme Lokal, PO : Pestisida Organik, JOK : Jam Orang Kerja

\section{Tenaga Kerja}

Penggunaan tenaga kerja per hektar luas lahan padi sawah mulai dari proses pengolahan lahan sampai dengan pasca panen (produksi beras) antar petani pengguna pupuk organik dan anorganik berbeda. Secara umum tingkat penggunaan tenaga kerja petani padi sawah pengguna pupuk organik lebih rendah dari petani pengguna pupuk semi-organik dan petani pengguna pupuk anorganik.Persentase penggunaan tenaga kerja petani pengguna pupuk organik 5,6 persen lebih rendah dibandingkan petani pengguna pupuk semiorganik atau 7 persen lebih rendah dibandingkan petani pengguna pupuk anorganik. Rendahnya penggunaan tenaga kerja pada petani pengguna pupuk organik disebabkan penyerapan tenaga kerja lebih sedikit pada penyemaian dan penanaman benih, serta tenaga kerja untuk pemupukan. 


\section{Pestisida}

Tingkat pemakaian pestisida petani pengguna pupuk anorganik lebih tinggi sebesar 6,40 liter per hektar dibandingkan petani pengguna pupuk semiorganik sebesar 1,5 liter per hektar dan petani pengguna pupuk organik sebesar 5,2 liter. Tingkat penggunaan pestisida ini lebih tinggi dibandingkan penggunaan pestisida oleh petani padi sawah di sentra produksi lainnya sebesar 0,43 liter per hektar untuk petani pengguna pupuk anorganik. Penggunaan pestisida terendah oleh petani pengguna pupuk semi-organik sebesar 1,11 persen sedangkan penggunaan pestisida petani pengguna pupuk organik sebesar 3,3 persen saja dari petani pengguna pupuk anorganik. Tingkat penggunaan pestisida rata-rata per hektar per musim tanam di tingkat petani relatif tinggi meskipun penggunaanya oleh petani telah dilakukan secara selektif dimana penggunaannya sangat ditentukan oleh intensitas serangan OPT. Hal ini dapat terjadi diduga kuat akibat penggunaan dosis tinggi serta waktu aplikasi kurang tepat. Penggunaan dosis tepat berdampak nyata atas pengurangan serangan OPT di sentra produksi beras di Kabupaten Seluma, Bengkulu (Hamdan, 2011).

\section{Struktur Biaya Usahatani}

Struktur usahatani padi mencakup struktur biaya, produksi,dan pendapatan yang diperoleh petani untuk satu musim tanam dapat dicermati pada Tabel 2. Secara umum struktur biaya produksi usahatani padi sawah dibagi atas dua yaitu biaya variabel dan biaya tetap. Rata-rata biaya variabel untuk usahatani padi sawah dengan variasi pupuk yang digunakan berbeda antar ketiganya. Biaya variabel rata-rata petani pengguna pupuk organik lebih besar dibandingkan petani pengguna pupuk semi-organik dan non-organik dengan tingkat perbedaan masing-masing berkisar 3,91 persen dan 1,3 persen. Sedangkan biaya tetap rata-rata untuk memproduksi gabah pada petani pengguna pupuk organik relatif lebih rendah dibandingkan petani pengguna pupuk an-organik meskipun tingkat perbedaannya hanya sekitar 0,5 persen. Kondisi ini menunjukkan bahwa pembebanan biaya tetap per satuan input tetap yang digunakan petani untuk menghasilkan gabah lebih rendah, sebaliknya pembebanan biaya variabel per satuan input variabel yang digunakan petani lebih besar pada petani pengguna pupuk organik di bandingkan petani pengguna pupuk lainnya.

Struktur biaya produksi komoditi padi sawah pada masing-masing petani pengguna pupuk berbeda - beda untuk tiap jenis biaya yaitu biaya tenaga kerja, biaya pupuk, biaya benih dan lain-lain. Pada petani pengguna pupuk organik struktur biaya produksi didominasi oleh kontribusi biaya tenaga kerja. Tingginya kontribusinya biaya tenaga kerja disebabkan oleh beberapa faktor antara lain intensitas curahan orang kerja tinggi di tiap musim tanam. Ketersediaan tenaga kerja keluarga rendah 1,75 HOK sehingga 
kebutuhan tenaga kerja luar keluarga tinggi. Tingkat upah harian berlaku saat penelitian relatif tinggi berkisar Rp.65.000 - Rp.70.000 untuk tenaga kerja pria maupun untuk tenaga kerja wanita. Tingkat upah ini relatif lebih tinggi dibandingkan tingkat upah di sentra produksi beras Bengkulu hanya berkisar Rp.40.000 - Rp.45.000 per hari (Widiono, 2008; Hamdan, 2011; Romdhon, 2013).

Kontribusi biaya pupuk terhadap biaya usahatani mencapai 3,20 persen. Komponen biaya pupuk organik dalam struktur biaya komponen organik terdiri dari biaya pupuk organik, mikrorganisme lokal, dan pestisida organik sangat dominan mencapai 78,02 persen. Komponen ini jauh lebih tinggi dua kali lipat dibandingkan komponen sejenis pada petani pengguna pupuk semiorganik (lihat Tabel 3). Secara umum kontribusi biaya pupuk organik terhadap pendapatan usahatani lebih besar dibandingkan kontribusi biaya pupuk secara keseluruhan yaitu 4,09 persen. Artinya, alokasi pendapatan untuk biaya pembelian pupuk organik lebih dominan dibandingkan alokasi pendapatan untuk komponen biaya pupuk secara menyeluruh. Kenaikan harga pupuk organik akan menyebabkan pendapatan diperoleh menurun sebesar persentase kontribusi biaya tersebut.

Tabel 2 Kontribusi Biaya Pupuk Organik dan Komponen Organik: Petani Pengguna Pupuk Organik

\begin{tabular}{clr}
\hline No & Uraian : Kontribusi & $\begin{array}{c}\text { Persentase } \\
(\%)\end{array}$ \\
\hline 1 & Biaya komponen organik terhadap biaya total Usahatani & 3,20 \\
2 & Biaya pupuk organik terhadap komponen biaya organik & 78,02 \\
3 & Biaya pupuk atas biaya total Usahatani & 4,08 \\
4 & Biaya Pupuk organik terhadap biaya variabel & 8,77 \\
5 & Biaya pupuk terhadap pendapatan Usahatani & 3,19 \\
6 & Biaya komponen organik terhadap pendapatan Usahatani & 4,09 \\
\hline
\end{tabular}

Sumber: Data Primer diolah, 2013

Pada petani pengguna pupuk semi-organik struktur biaya produksi relatif sama yaitu didominasi oleh kontribusi biaya tenaga kerja. Berdasarkan Tabel 3 diketahui bahwa kontribusi biaya pupuk organik atas biaya produksi pada petani pengguna pupuk semiorganik mencapai 7 persen. Persentase ini lebih besar dibandingkan kontirbusi sejenis pada petani pengguna pupuk organik. Namun komponen biaya pupuk organik terhadap komponen organik relatif lebih kecil dibandingkan kontribusi biaya pupuk organik terhadap komponen organik yaitu separuh dari petani pengguna pupuk organik.

Atas pendapatan usahatani padi sawah kontribusi biaya pupuk pada petani pengguna pupuk semiorganik relatif kecil hanya sebesar 2,61 persen, demikian pula kontribusi biaya pupuk organik relatif sama yaitu sebesar 2,57 
persen. Kontribusi ini lebih kecil dibandingkan kontribusi komponen biaya yang sama pada petani pengguna organik. Artinya alokasi pendapatan untuk biaya pembelian pupuk relatif kecil dibandingkan alokasi pendapatan untuk komponen biaya lainnya. Hal ini mengindikasikan peluang penggunaan pupuk organik pada usahatani padi sawah relatif besar.

Tabel 3 Kontribusi Biaya Pupuk, Pupuk Organik dan Komponen Organik: Petani Pengguna Pupuk Semi-Organik

\begin{tabular}{clr}
\hline No & \multicolumn{1}{c}{ Uraian : Kontribusi } & Persentase \\
\hline 1 & Biaya pupuk terhadap total biaya usahatani padi & 7,10 \\
2 & Biaya pupuk organik atas total biaya usahatani & 3,33 \\
3 & Biaya pupuk organik atas biaya total biaya pupuk & 46,94 \\
4 & Biaya pupuk organik atas biaya total biaya variabel & 4,75 \\
5 & Biaya pupuk atas biaya total biaya variabel & 10,13 \\
6 & Biaya pupuk atas pendapatan usahatani & 2,61 \\
7 & Biaya pupuk organik atas pendapatan usahatani & 2,57 \\
\hline
\end{tabular}

Sumber: Data Primer diolah, 2013

Petani pengguna pupuk anorganik persentase biaya pupuk terhadap total biaya usahatani padi sawah lebih rendah dibandingkan biaya pupuk petani pengguna pupuk semiorganik namun lebih tinggi dari biaya pupuk petani pengguna pupuk organik. Kontribusi biaya pupuk atas biaya variabel pada petani pengguna pupuk jenis ini lebih rendah dibandingkan petani pengguna pupuk jenis lainnya dengan perbedaan mencapai $2-4$ persen. Hal ini diduga kuat menjadi salah satu aspek yang mendorong petani tetap mengutamakan pemakaian pupuk anorganik pada usahatani padi sawah. Aspek lainnya, antara lain ketersediaan pupuk anorganik di pasar, harga pupuk masih di subsidi pemerintah sehingga relatif terjangkau petani.

Tabel 4. Kontribusi Biaya Pupuk: Petani Pengguna Pupuk Anorganik

\begin{tabular}{clc}
\hline No & Uraian : Kontribusi & Persentase \\
\hline 1 & Biaya pupuk terhadap biaya total usahatani & 4,90 \\
2 & Biaya pupuk terhadap biaya variabel & 6,97 \\
3 & Biaya pupuk terhadap pendapatan & 4,90 \\
\hline
\end{tabular}

Sumber: Data Primer diolah, 2013

Kontribusi biaya pupuk terhadap pendapatan pada petani pengguna pupuk anorganik lebih tinggi dari kontribusi biaya pupuk atas pendapatan padi petani pengguna pupuk semiorganik dan pupuk organik. Persentase kontribusi biaya pupuk terhadap biaya total usahatani dan pendapatan dengan 
besaran yang sama. Hal ini berarti adanya kenaikan harga pupuk anorganik akan menyebabkan pendapatan diperoleh menurun sebesar persentase kontribusi biaya tersebut.

\section{Struktur Produksi dan Pendapatan}

\section{Produksi Gabah dan Beras}

Struktur produksi dan pendapatan usahatani padi penggguna pupuk organik, anorganik dan semiorganik mencakup aspek kuantitas produksi, harga, penerimaan dan pendapatan gabah dan beras. Tabel 2 menunjukkan struktur produksi petani padi sawah dapat dibagi atas produksi gabah, beras dan bekatul (jerami).

Tingkat produksi gabah dan beras dihasilkan petani padi pengguna pupuk semi-organik lebih tinggi dibandingkan petani pengguna pupuk lainnya. Secara umum produksi terendah dicapai petani padi untuk semua kategori pupuk relatif sama berkisar 8,1 - 8,9 ton per hektar. Rata-rata produksi Gabah Kering Giling (GKG) per hektar petani pengguna pupuk semiorganik lebih tinggi dibandingkan petani pengguna pupuk lainnya. Persentase perbedaan produksi GKG antara petani pengguna pupuk orgnaik dengan petani pengguna pupuk semi-organik mencapai 8,18 persen, dan petani pengguna pupuk anorganik mencapai 13,64 persen.

Produksi beras per hektar petani pengguna pupuk semi organik juga lebih tinggi dibandingkan petani pengguna pupuk lainnya. Perbedaan produksi gabah petani pengguna pupuk semi-organik dengan petani pengguna pupuk organik mencapai 5 persen, dengan petani pengguna pupuk anorganik mencapai 10,47 persen. Sedangkan perbedaan produksi petani pengguna pupuk organik dan petani pengguna pupuk anorganik mencapai 5,1 persen. Rata-rata rendemen produksi beras petani hanya berkisar rata-rata 44,51 - 48,64 persen dari produksi gabah dihasilkan.Rendemen ini lebih rendah dari rendemen produksi gabah menjadi beras berkisar 60 persen di sejumlah sentra produksi padi lainnya. Hal ini menunjukkan tingkat kehilangan (loss of production) potensi produksi relatif besar dalam pengolahan gabah menjadi beras pada semua petani pengguna pupuk berbeda. Artinya, peluang peningkatan produksi beras masih terbuka dengan menekan kehilangan produksi, baik kehilangan produksi di tingkat petani pengolah maupun pabrik pengolahan gabah menjadi beras.

\section{Harga Gabah dan Beras}

Harga gabah dan beras menjadi salah satu variabel produksi yang ditentukan oleh faktor diluar petani. Harga output ditentukan oleh mekanisme pasar berlaku di tingkat petani. Secara umum baik harga gabah maupun harga beras yang diterima petani pengguna pupuk organik lebih tinggi dibandingkan 
harga yang diterima petani pengguna pupuk lainnya. Harga diterima petani pengguna pupuk organik sebesar Rp.4.100 per $\mathrm{kg}$, dibandingkan petani pengguna pupuk lainnya hanya sebesar Rp.3.300 per kg. Persentase harga gabah diterima petani pengguna pupuk organik mencapai 19,51 persen lebih tinggi dibandingkan harga gabah diterima petani pengguna pupuk lainnya. Harga gabah organik juga lebih tinggi dari harga gabah non-organik di sentrasentra produksi beras lainnya seperti di Bengkulu dan harga gabah ketetapan pemerintah (Romdhon, 2013).

Namun bila petani menjual hasil produksi dalam bentuk beras organik, maka harga diterima petani pengguna pupuk organik lebih besar dari petani pengguna pupuk lainnya dengan perbedaan harga mencapai 27,58 persen. Hal ini mengimplikasikan pemberian nilai tambah melalui perubahan bentuk produk dari gabah ke beras meningkatkan nilai jual produk mencapai 8,07 persen dengan biaya produksi untuk mengubah produk relatif sama antar petani pengguna pupuk berbeda.

\section{Pendapatan Petani}

Sumber pendapatan petani padi sawah pengguna pupuk berbeda disajikan pada Tabel 4, dapat dibagi atas dua yaitu pendapatan gabah atau beras dan bekatul (jerami). Pendapatan petani padi pengguna pupuk organik lebih tinggi dibandingkan pendapatan petani pengguna pupuk anorganik dan petani pengguna pupuk semi-organik. Pendapatan lebih tinggi dari pendapatan petani padi non-organik di sejumlah negara misal Bangladesh, Pakistan, dan Cina (Rahman, 2003; Abdulai, et al, 2000; Ali dan Flynn, 1989). Meskipun tingkat produksi gabah atau beras dihasilkan relatif lebih rendah dibandingkan petani pengguna pupuk lainnya. Namun secara umum tingkat pendapatan petani pengguna pupuk organik lebih tinggi dibandingkan petani pengguna pupuk lainnya. Pendapatan produksi beras atau pendapatan total usahatani petani pengguna pupuk organik mencapai 1,55 kali lipat dibandingkan petani lainnya.

Tinggi pendapatan petani pengguna pupuk organik sangat ditentukan oleh harga jual gabah atau beras di tingkat petani. Dengan kapasitas produksi masih terbatas terindikasi dari jumlah petani beras organik dan luasan garapan relatif terbatas. Di sisi lain permintaan beras organik relatif tinggi saat ini untuk konsumsi langsung masyarakat atau permintaan pedagang, maka harga jual beras organik relatif tinggi. Oleh karena itu harga jual beras organik menjadi faktor sangat menentukan tingkat pendapatan petani. Harga jual beras diterima petani pengguna pupuk organik mencapai 1,38 kali lebih tinggi dibandingkan harga petani pengguna pupuk lainnya. Harga jual ini lebih tinggi dari harga jual beras di sentra beras lain misal di Bengkulu (Romdhon, 2013). 


\section{Perbedaan Biaya dan Pendapatan Usahatani Padi Sawah: Petani Pengguna Pupuk Organik, Semiorganik, dan Anorganik.}

Kontribusi biaya pupuk secara umum pada petani pengguna pupuk semi-organik lebih besar dibandingkan petani pengguna pupuk organik serta petani pengguna pupuk an-organik. Perbandingan besaran kontribusi biaya pupuk tersebut mencapai 2 kali lipat terhadap petani pengguna pupuk organik dan mencapai 1,5 kali lipat terhadap petani pengguna pupuk anorganik. Pertanyaan penting atas fenomena ini adalah apakah besaran kontribusi dimaksud menunjukkan suatu perberbedaan nyata secara statistik. Untuk itu perlu dilakukan uji beda nyata atas perbedaan biaya dan pendapatan antar usahatani padi sawah pengguna pupuk berbeda.

Uji ini ditentukan berdasarkan nilai $\mathrm{t}$ pendapatan petani pengguna pupuk berbeda. Uji $t$ statistik perbedaan pendapatan antar petani pengguna pupuk organik - petani pengguna pupuk anorganik, petani pengguna pupuk organik - petani pengguna pupuk semi-organik dan petani pengguan pupuk semi-organik dengan petani pengguna pupuk anorganik. Hasil uji t terhadap perbedaan pendapatan ini akan memberikan beberapa implikasi bagi pengembangan usahatani padi sawah khususnya bagi petani pengguna pupuk organik. Implikasi produksi memberikan gambaran prospek pengembangan usahatani padi organik di tingkat petani dalam kaitannya dengan kuantitas petani beras organik serta ketersediaannya di pasar. Hasil analisis ini pula memberikan implikasi bagi pengembangan usaha dan peluang pasar pupuk organik di tingkat petani dan ketersediaannya di tingkat pedagang pupuk.

Tabel 5 Perbedaan Pendapatan antar Petani Padi Pengguna Pupuk Organik, Semiorganik dan Anorganik

\begin{tabular}{lccc}
\hline \multirow{2}{*}{\multicolumn{1}{c}{$t_{\text {hit }}$}} & \multicolumn{3}{c}{ Pendapatan } \\
\cline { 2 - 4 } & OSO & OAN & SOAN \\
\hline Equal variance & 0.55754841 & $2.70416 \mathrm{E}-69$ & $2.14382 \mathrm{E}-05$ \\
Unequal variance & 0.47367567 & $3.99202 \mathrm{E}-71$ & $5.23054 \mathrm{E}-06$ \\
\hline Ke
\end{tabular}

Keterangan: Jumlah Sampel petani: Organik: 81, Semi-organik : 122, Anorganik : 101; OSO : Organik - Semiorganik, OAN : Organik - Anorganik, SOAN : Semiorganiks - Anorganik., pendapatan usahatani padi sawah (beras+bekatul)

Tabel 5 menunjukkan hasil uji $\mathrm{t}$ antar pendapatan petani pengguna pupuk organik - semiorganik, organik - anorganik dan semiorganik anorganik. Secara umum hasilnya menunjukkan kecenderungan yang sama bahwa tidak ada perbedaan nyata pendapatan petani pengguna pupuk berbeda. Uraian berikut merupakan hasil uji t petani pengguna pupuk organik - semi organik. Berdasarkan hipotesis ditentukan yaitu: 
H0: Tidak ada perbedaan antara rata-rata pendapatan petani pengguna pupuk organik dengan petani pengguna pupuk semiorganik

Ha: Ada perbedaan antara antara rata-rata pendapatan petani pengguna pupuk organik dengan petani pengguna pupuk semiorganik

Pengujian menggunakan uji dua sisi dengan tingkat signifikansi $\alpha=5 \%$. Tingkat signifikansi dalam hal ini berarti kita mengambil risiko salah dalam mengambil keputusan untuk menolak hipotesis yang benar sebanyakbanyaknya 5\%. Dari Tabel 5 di atas nilai t hitung (equal variance assumed) adalah 0.558. Tabel distribusi t dicari pada $\alpha=5 \%: 2=2,5 \%$ (uji 2 sisi) dengan derajat kebebasan (df) $203-2=201$ diperoleh $\mathrm{t}$ tabel sebesar 1,971, maka nilai $t_{\text {hitung }}<t_{\text {tabel }}(0,558<1.971)$ yang berarti H0 diterima. Artinya, tidak ada perbedaan antara rata-rata pendapatan petani pengguna pupuk organik dengan petani pengguna pupuk semiorganik serta petani pengguna pupuk anorganik.

Hasil uji $\mathrm{t}$ memberikan implikasi khususnya terhadap produksi gabah atau beras organik dan penggunaan pupuk organik. Perbedaan pendapatan yang tidak nyata diduga kuat menyebabkan petani padi sawah belum memberikan insentif tinggi bagi petani untuk beralih ke padi organik. Fenomena riil juga menunjukkan bahwa petani dihadapkan pada situasi pasar beras oligopsoni sehingga petani sebagai pricetaker. Para tengkulak (tauke beras) tidak jarang membeli beras tanpa mempertimbangkan kualitas (apakah beras tersebut organik atau beras anorganik). Upaya lain dapat dilakukan melalui peningkatan kualitas panen dan pengolahan gabah menjadi beras sehingga menekan kehilangan hasil selama proses dan pasca panen di tingkat petani. Hal ini akan mendorong peningkatan produksi gabah dan beras terutama padi petani pengguna pupuk organic yang pada gilirannya akan meningkatkan pendapatan seiring harga beras organik lebih tinggi di pasar.

Di sisi lain petani umumnya terikat pinjaman modal operasional untuk memproduksi beras kepada para tengkulak yang dibayar setelah panen (yarnen). Akibatnya harga beras diterima lebih rendah dari seharusnya. Kondisi ini dapat dicarikan solusi dengan mendorong pembentukan pasar beras organik bersifat inklusif. Artinya beras organik petani dipasarkan pada pasar tertentu (captive market) ke konsumen atau pembeli tertentu sehingga seluruh produk beras organik terserap oleh pasar.

Hasil analisis juga berimplikasi terhadap tingkat pemakaian pupuk organik secara riil lebih tinggi dibandingkan tingkat pemakaian pupuk anorganik atau pupuk semi-organik. Kuat dugaan hasil pendapatan tidak berbeda nyata secara statistik mendorong rendahnya penggunaan pupuk organik di tingkat petani padi. Di sisi lain biaya pupuk dalam struktur biaya produksi padi sawah lebih besar karena harga jual pupuk organik relatif lebih mahal terutama pupuk atau pestisida organik yang diperdagangkan. 
Kondisi ini juga berkontribusi atas rendahnya penggunaan pupuk organik di tingkat petani. Hal ini terindikasi dari lambatnya pertumbuhan penggunaan pupuk organik di tingkat petani padi. Oleh karena itu, upaya mengakselerasi penggunaan pupuk organik di tingkat petani harus dilakukan secara melembagakan. Kelembagaan dimaksud melalui aktifitas penyuluhan, demoplot penggunaan pupuk organik terutama oleh badan penyuluhan pangan pemerintah, serta memberikan insentif produksi bagi petani pelaku usahatani organik seperti bantuan input produksi serta permodalan operasional, serta insentif pasar lainnya seperti harga beras dan penciptaan akses pasar beras organik yang besar.

Tabel 6. Statistik Deskriptif Struktur Biaya dan Pendapatan Usahatani Padi di Sentra Produksi Kabupaten OKU Timur (OKUT)

\begin{tabular}{|c|c|c|c|c|c|c|c|c|c|c|c|c|c|c|}
\hline \multirow{3}{*}{ No } & \multirow{3}{*}{ Var } & \multirow{3}{*}{\begin{tabular}{|c|} 
\\
\end{tabular}} & \multicolumn{12}{|c|}{ Statistik Deskriptif Usahatani Padi Sawah } \\
\hline & & & \multicolumn{4}{|c|}{ Non-Organik } & \multicolumn{4}{|c|}{ Semi Organik } & \multicolumn{4}{|c|}{ Organik } \\
\hline & & & 1 & 2 & 3 & 4 & 1 & 2 & 3 & 4 & 1 & 2 & 3 & 4 \\
\hline \multirow[t]{6}{*}{$\mathrm{A}$} & B.Var & $\mathrm{Rp} / \mathrm{Ha}$ & 10,894 & 9,346 & 17,822 & 1,521 & 10,606 & 9,141 & 12,696 & 653 & 11,037 & 9,871 & 17,209 & 1,429 \\
\hline & B.Ttp & Rp/Ha & 4,595 & 4,271 & 4,909 & 158 & 4,554 & 4,284 & 4,884 & 149 & 4,572 & 3,829 & 4,882 & 203 \\
\hline & Prod. & $\mathrm{Kg} / \mathrm{Ha}$ & 9,5 & 8,9 & 15,1 & 1,3 & 11 & 8,1 & 13,8 & 1,2 & 10,1 & 8,8 & 10,7 & 0.36 \\
\hline & $\mathrm{Hrg}$ & $\mathrm{Rp} / \mathrm{kg}$ & 3,3 & 3,3 & 3,4 & 0.02 & 3,3 & 3,3 & 3,6 & 0.051 & 4,1 & 3,8 & 8,9 & 1,1 \\
\hline & Pnrm & Rp/Ha & 31,549 & 29,403 & 49,962 & 4,242 & 35,399 & 27,306 & 45,566 & 3,579 & 41,258 & 33,440 & 91,136 & 11,535 \\
\hline & Pdpt & Rp/Ha & 24,036 & 14,105 & 45,598 & 6,357 & 20,237 & 13,292 & 28,275 & 2,933 & 33,553 & 22,442 & 80,275 & 10,791 \\
\hline \multirow[t]{5}{*}{ B } & Prod. & $\mathrm{Kg} / \mathrm{Ha}$ & 4,621 & 4,330 & 7,358 & 633 & 5,156 & 3,957 & 6,711 & 508 & 4,913 & 4,277 & 5,210 & 175 \\
\hline & Hrg & $\mathrm{Rp} / \mathrm{kg}$ & 6,788 & 6,700 & 7,059 & 69 & 6,788 & 6,700 & 6,987 & 61 & 9,373 & 9,000 & 9,900 & 378 \\
\hline & Pnrm & Rp/Ha & 31,367 & 29,013 & 49,556 & 4,307 & 35,008 & 26,985 & 46,102 & 3,510 & 46,070 & 38,491 & 49,269 & 2,716 \\
\hline & B.Prod. & Rp/ha & 16,163 & 14,251 & 23,079 & 1,613 & 15,695 & 14,405 & 18,104 & 819 & 16,124 & 14,651 & 22,398 & 1,449 \\
\hline & Pdpt & Rp/ha & 15,205 & 7,227 & 31,649 & 4,275 & 19,313 & 12,580 & 27,999 & 2,691 & 29,946 & 22,845 & 33,937 & 2,919 \\
\hline \multirow[t]{3}{*}{ C } & Prod. & $\mathrm{Kg} / \mathrm{Ha}$ & 0,190 & 0,178 & 0,303 & 0,026 & 0,212 & 0,163 & 0,276 & 0,021 & 0,202 & 0,176 & 0,214 & 0,007 \\
\hline & $\mathrm{Hrg}$ & $\mathrm{Rp} / \mathrm{kg}$ & 0,858 & 0,825 & 0,950 & 0,024 & 0,868 & 0,825 & 0,950 & 0,031 & 0,877 & 0,850 & 1 & 0,047 \\
\hline & Pdpt & Rp/ha & 163,267 & 149,985 & 257,380 & 23,305 & 184,282 & 140,896 & 234,736 & 19,258 & 177,253 & 149,600 & 197,632 & 10,319 \\
\hline D & Pdpt & $\mathrm{Rp} / \mathrm{Ha}$ & 15,368 & 7,377 & 31,907 & 4,296 & 19,497 & 12,695 & 28,348 & 2,838 & 30,123 & 22,995 & 34,112 & 2,923 \\
\hline E & & & $n=101$ & & & & & $n=122$ & & & & $n=81$ & & \\
\hline
\end{tabular}

Keterangan: * berlaku kecuali untuk luas lahan dan umur, A :: Gabah, B : Beras, C : Bekatul, D: UT (Usahatani), dan E : Sampel : 1 : mean, 2 : minimum, 3 : maksimum, 4 : standar deviasi

\section{SIMPULAN DAN SARAN}

\section{Simpulan}

Kesimpulan diberikan berdasarkan hasil dan pembahasan tentang perbedaan pendapatan petani pengguna pupuk organik dan anorganik adalah:

1. Kontribusi biaya pupuk pada petani pengguna pupuk semi-organik lebih besar dibandingkan petani pengguna pupuk organik serta pupuk anorganik. 
2. Berdasarkan hasil uji $\mathrm{t}$ diperoleh kesimpulan tidak ada perbedaan nyata antara rata-rata pendapatan petani pengguna pupuk organik dengan petani pengguna pupuk semiorganik serta petani pengguna pupuk anorganik. Hal ini belum memberikan insentif tinggi bagi petani untuk beralih dari memproduksi padi non-organik ke padi organik.

\section{Saran}

Upaya mengakselerasi penggunaan pupuk organik di tingkat petani harus dilakukan secara kelembagaan melalui penyuluhan, demplot, serta memberikan insentif produksi dan pasar bagi pelaku usahatani organik.

\section{DAFTAR PUSTAKA}

Abdulai, A and Wallace, H. 2000. An Examination of Profit Inefficiency of Rice Farmers in Northern Ghana. International Journal of Agricultural Economics and Rural Development-1: (1). Iowa.

Ali, M dan Flynn, J.C. 1989. Profit Efficiency among Basmati Rice Producers in Pakistan Punjab. American Journal of Agricultural Economics 71(2) : 303-310.

Anonimous. 2012. Statistik Tanaman Pangan dan Hortikultura. Dinas Tanaman Pangan dan Hortikultura Provinsi Sumatera Selatan, Palembang.

Hamdan. 2011. Ekonomi Konversi Lahan Sawah Menjadi Kebun Kelapa Sawit di Kecamatan Seluma Selatan Kabupaten Seluma Provinsi Bengkulu, Thesis (tidak dipublikasikan), Sekolah Pascasarjana IPB, Bogor.

Rahman, S. 2003. Profit Efficiency among Bangladesh Rice Farmers, Food Policy, $28: 483-503$.

Romdhon, M.M. 2013. Optimalisasi Lahan Sawah untuk Memenuhi Target Pendapatan Petani Setara Pendapatan Perkebunan di Provinsi Bengkulu: Pendekatan Stochastic Profit Frontier dan Goal Programming. Program Doktor Fakultas Pertanian UNSRI, Palembang.

Sahara dan Idris. 2005. Efisiensi Produksi Sistem Usahatani Padi pada Lahan Sawah Irigasi Teknis. Laporan Penelitian, Balai Pengkajian Teknologi Pertanian (BPTP) Sulawesi Tenggara, Kendari.

Swastika, D.K.S., P.U. Hadi, dan Nyak Ilham. 2000. Proyeksi Penawaran dan Permintaan Komoditas Tanaman Pangan. Pusat Penelitian Sosial Ekonomi Pertanian, Bogor.

Widiono, S. 2008. Pembangunan Perkebunan Kelapa Sawit serta Dampaknya terhadap Pelapisan Sosial dan Strategi Nafkah (Kasus Dua Desa Sawah Etnis Serawai dan Jawa di Kabupaten Seluma, Bengkulu). Tesis IPB, Bogor (tidak dipublikasikan). 